ENTREPRENEURSHIP AND SUSTAINABILITY ISSUES

ISSN 2345-0282 (online) http://jssidoi.org/jesi/ 2020 Volume 8 Number 1 (September)

http://doi.org/10.9770/jesi.2020.8.1(81)
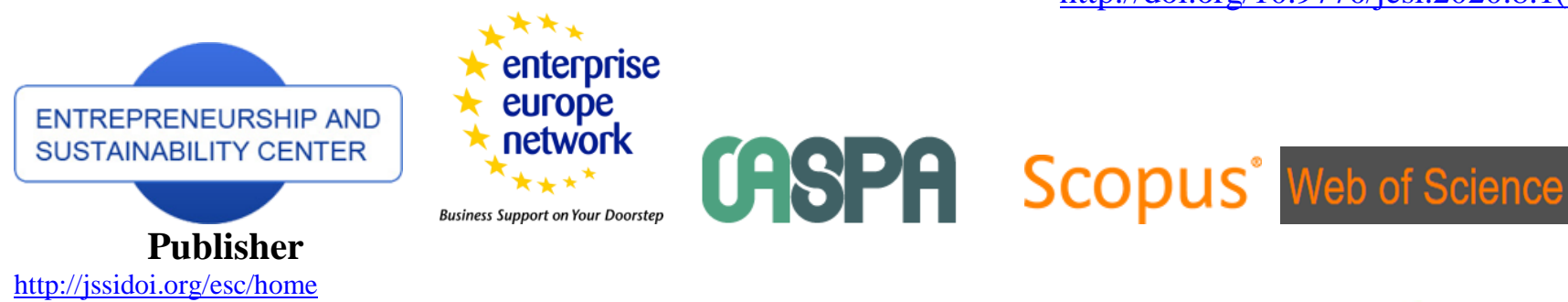

http://jssidoi.org/esc/home

Business Support on Your Doorstep

Clarivate
Analytics

\title{
DEVELOPMENT OF ENVIRONMENTAL PILLAR IN THE CONTEXT OF CIRCULAR ECONOMY ASSESSMENT: BALTIC SEA REGION CASE
}

\author{
Marta Nikanorova ${ }^{1}$, Jelena Stankevičienė ${ }^{2}$ \\ 1,2 Vilnius Gediminas Technical University, Faculty of Business Management, Department of Financial Engineering, \\ Sauletekio al. 11, Vilnius, LT-10223, Lithuania \\ E-mails: ${ }^{1}$ marta.nikanorova@vgtu.com; ${ }^{2}$ jelena.stankeviciene@vgtu.lt
}

Received 15 May 2020; accepted 8 August 2020; published 30 September 2020

\begin{abstract}
Circular Economy (CE) is an economic approach which aims to save the environment by eliminating waste and efficiently using resources by applying recycle, reuse, repair, remanufacturing and recycling strategies. The purpose of the article is to propose a concept of measurement the development of Environmental pillar in the context of Circular Economy, apply and provide empirical evidence based on the data of Baltic Sea Region countries. The research augmented for the analysis of Circular Economy which includes assessment model creation. The multi-criteria decision methods MULTIMOORA and TOPSIS were used to assess the development of Environmental pillar of Circular Economy in Baltic Sea Region. Results are useful to add to theoretical building and evaluate the Environmental aspect in the concept of Circular Economy.
\end{abstract}

Keywords: circular economy; circular economy indicators; environmental indicators; circular economy strategies; MULTIMOORA; TOPSIS

Reference to this paper should be made as follows: Nikanorova, M.; Stankevičienè, J. 2020. Development of environmental pillar in the context of circular economy assessment: Baltic Sea Region case, Entrepreneurship and Sustainability Issues, 8(1), 1209-1223. http://doi.org/10.9770/jesi.2020.8.1(81)

JEL Classifications: D7, O11, O44, O52

\section{Introduction}

Circular economy approach can be represented as a closed loop with the material and process flow ensuring zero waste in every step of the production or product consumption. Circular economy is seeking to minimize material input, water, land and air pollution. Circular economy seeks to integrate strategies that would help to achieve a zero-waste aim - recycling, remanufacturing, repair, reuse, reduce and others to turn the waste into the resource for another process. Circular economy approach corresponds to sustainable development and sustainability goals, seeking well-being in a long term, consists of three pillars: environment, economic and social. Many countries have already created some strategies to implement circular economy approach, however, still there are concerns about circular economy assessment model creation. Integration of circular economy is relatively new approach, which actively is being discussing among scientists. Circular economy is a multi-disciplinary approach, which connects environmental and social sciences. Thus, assessment model with the possibility to analyze circular 


\section{ENTREPRENEURSHIP AND SUSTAINABILITY ISSUES}

ISSN 2345-0282 (online) http://jssidoi.org/jesi/

2020 Volume 8 Number 1 (September)

http://doi.org/10.9770/jesi.2020.8.1(81)

economy as a whole concept and its pillars separately would be useful to evaluate todays situation, see the dynamics of the development by areas and integrate the assessment model in other model which would analyze circular economy and lead to its integration.

\section{Circular Economy strategies and targets}

Circular economy became a popular approach for policy makers, government and scientists to discuss about transition from linear economy to circular economy contributing to sustainable development. Today, in the times of economic growth and technological development, huge volumes of economy brought a negative impact on environment - the greenhouse effect, air, water and pollution, scarcity of materials and many others. Linear economy model helped society to build effective business models, which aimed to increase production and volumes. However, environmental problems became a very popular topic to discuss recent years, as many environmental changes we are facing now due to human activities.

Circular economy approach offers a decision how to keep economy healthy and reduce the harmful environmental activities. Circular economy offers new approach based on re-use, reduce and recycling of materials (Morseletto, 2020). Circular economy promotes the idea of reducing waste and resources used, replacing them by recycled and re-used materials (Homrich et al., 2018). China was one of the first countries who officially has started promoting circular economy concepts (Geng, et al., 2008; Li, et al., 2007). However, circular economy concept was related to economic and environmental pillars in china making circular economy concept highly related to environment and less to social pillar (Geng et al., 2012; Ghisellini et al., 2016).

Lately, many authors discussed about the necessity of social pillar to be included in circular economy model as social pillar represent human well-being as the aim of circular economy (Nikanorova et al., 2020). Circular economy corresponds to the sustainable development goals (Schroeder, et al., 2018) and includes environment, economic and social dimensions. According to m. Lewandowski (2016), many different size enterprises are becoming to implement the concepts of circular economy. European union has introduced an action plan about circular economy implementation across the member states (EC, 2015). In 2018 european commission has introduced key indicators for a monitoring circular economy development grouped in following classifications (CE, 2018):

1. Self-sufficiency for raw materials

2. Green public procurement

3. Waste generation

4. Food waste

5. Recycling rates

6. Recycling / recovery for specific waste streams

7. Contribution of recycled materials to raw materials demand

8. Trade in recyclable raw materials

9. Private investments, jobs and gross value added

10. Patents related to recycling and secondary raw materials

Mainly, the indicators suggested by CE (2018) are related to responsible production and consumption. Green public procurement (2), Waste generation (3), Food waste (4), Recycling rates (5), Recycling / recovery for specific waste streams (6) are connected with common EU target on Waste Management. Moreover, indicators to measure Waste Management are coming from earlier EU policy related to resource efficiency (EC, 2011). According to P. Repo, et al., (2018), A. Bjørn et al., (2017), P. Morseleto (2020) studies on EU targets they can be classified according to area or object of targets in several groups:

- Recycling

- Resource Efficiency 
- Waste reduction

- Energy recovery

- Water recovery

- Emission reduction

- Design

Indicators proposed by EU for circular economy development monitoring can be grouped by the EU strategies, area of the target or object of the target. J. Potting, et al., (2017) has introduced 10R circular economy strategies (Table 1).

Table 1. 10R Circular Economy strategies

\begin{tabular}{|l|l|l|l|}
\hline R0 & Refuse & R5 & Refurbish \\
\hline R1 & Rethink & R6 & Remanufacture \\
\hline R2 & Reduce & R7 & Repurpose \\
\hline R3 & Reuse & R8 & Recycle \\
\hline R4 & Repair & R9 & Recovery \\
\hline
\end{tabular}

Source: Potting, et al., 2017

The strategies, represented in Table 2 are classified by circularity level, which means, that R0 has the lowest circularity level, while R9 has the highest circularity level. R0 Refuse strategy lets the product be unnecessary by abandoning its function or which can be easily replaced by different product. By R1 Rethink strategy the product is being used more intensively (multi-functional products), while R2 Reduce strategy increases efficiency of product manufacture or consuming less natural resources. R3 Reuse strategy offers to reuse the product by another customer, while the product is still in a good condition. R4 Repair strategy allows product to be modified or repaired, while R5 Refurbish strategy restores an old product up to date. R6 Remanufacture allows to use parts of discarded product in a new product with the same function, while R7 Repurpose strategy allows to use parts of discarded product or its part in a new product with different function. R8 Recycle strategy allows to process materials to obtain the same or lower quality. R9 Recovery strategy has the highest circularity level and allows incineration of material with energy recovery.

\section{Selection of indicators for monitoring environmental pillar of circular economy}

Environmental pillar of Circular Economy should include a complex set of indicators covering the targets and strategies set by European Union. The indicators could be classified by the area of target or Circular Economy strategies.
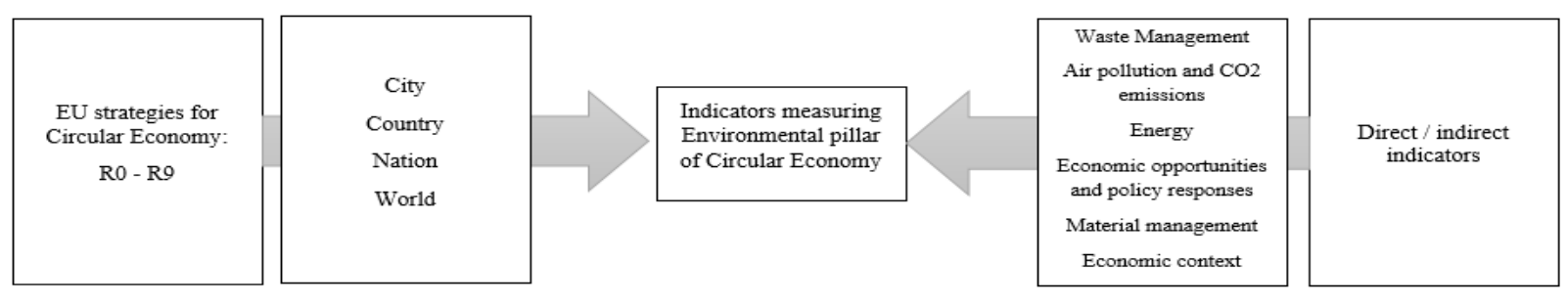

Figure 1. Indicators selection strategy to assess Environmental pillar of Circular Economy.

Source: created by authors 
Direct and indirect indicators for assessment of Environmental pillar have been selected according to the definition and principles of Circular Economy with the correlation of European Union strategies and targets (Fig. 1). Indicators of Environmental pillar are divided into six groups related to the areas of European Union targets for Circular Economy. Also, strategies of European Union are being selected according to the scope of research from micro level including product, product creation steps - to macro - analysis of cities, regions, nations or world.

In this research Circular Economy is being analyzed only by Environmental and Economic pillars, however it is possible to analyze Circular Economy including all the pillars: Environmental, Social and Economic. Ability to analyze one of the pillars separately would have benefits of the possibility to follow the development of separate pillar or part of the pillar represented as a group of indicators.

Table 2. Indicators for assessment Environmental pillar of Circular Economy

\begin{tabular}{|c|c|c|}
\hline Area of target & Indicator & Strategy \\
\hline \multirow{4}{*}{ Waste Management } & Municipal waste generated & R2, R3 \\
\hline & Recycling rate of municipal waste & R8 \\
\hline & Recycling rate of e-waste & $\mathrm{R} 8$ \\
\hline & Recycling of bio waste & R8 \\
\hline \multirow{4}{*}{$\begin{array}{c}\text { Air pollution and } \mathrm{CO} 2 \\
\text { emissions }\end{array}$} & $\mathrm{CO} 2$ Emission Intensity & R0, R2 \\
\hline & Production-based $\mathrm{CO} 2$ emissions & R0, R1, R2 \\
\hline & Air pollution exposure & R0, R1, R2 \\
\hline & Greenhouse gas emissions & R0, R1, R2 \\
\hline \multirow{4}{*}{ Energy } & Renewable electricity, \% total electricity generation & $\mathrm{R} 4$ \\
\hline & Energy intensity & $\mathrm{R} 4$ \\
\hline & Energy productivity & $\mathrm{R} 4$ \\
\hline & Renewable energy supply & R9 \\
\hline \multirow{4}{*}{$\begin{array}{c}\text { Economic opportunities } \\
\text { and policy responses }\end{array}$} & Environmentally related ODA, $\%$ total ODA & R6 \\
\hline & Environmentally related taxes, \% GDP & R0, R1, R2 \\
\hline & Green Patents & R2,R5,R6 \\
\hline & Jobs in Green Technology Industry & R2,R5,R6 \\
\hline \multirow{3}{*}{ Material Management } & Circular material use rate & R6,R7,R8,R9 \\
\hline & Non-energy material productivity & R2, R3 \\
\hline & Trade in recyclable raw materials & $\mathrm{R} 8$ \\
\hline \multirow{4}{*}{ Economic context } & Real GDP & $\mathrm{R} 2$ \\
\hline & Value added in industry, $\%$ of total value added & $\mathrm{R} 2$ \\
\hline & Value added in services, $\%$ of total value added & R2 \\
\hline & Value added in agriculture, $\%$ of total value added & R2 \\
\hline
\end{tabular}

Source: created by authors

In Table 2 the indicators that have direct and indirect impact are classified into the group according to the area of targets of European Union for Circular Economy. Classified indicators correspond to the European Union strategies for Circular Economy. Indicators, representing macro-level have been selected to evaluate countries and regions.

Indicators are being classified into six groups: waste management, air pollution and $\mathrm{CO}_{2}$ emissions, energy, economic opportunities and policy responses, material management and economic context. Waste management group of indicators is focused on the reduction of municipal waste generated and recycling of municipal, bio waste and e-waste what corresponds to one of the most important aspects of circular economy - zero waste approach. Air pollution and $\mathrm{CO}_{2}$ emissions group measures $\mathrm{CO}_{2}$ emissions intensity and production-based co2 


\section{ENTREPRENEURSHIP AND SUSTAINABILITY ISSUES}

ISSN 2345-0282 (online) http://jssidoi.org/jesi/ 2020 Volume 8 Number 1 (September) http://doi.org/10.9770/jesi.2020.8.1(81)

emissions, including air pollution and greenhouse gas emissions - corresponds to air pollution reduction approach of circular economy. Energy group of indicators concentrates on the quantity of renewable energy is being produced and used in production or households - corresponds to the circular economy approach of green energy. Economic opportunities and policy responses group of indicators analyses the financing of green policies, green patents and number of jobs in green technology industry corresponding to circular economy approach of promoting eco-technologies and eco-innovations. Material management group includes material management aspects as well as material circularity and recycling of materials. Economic context connects environmental and economic pillars, by the indicating whether the economy is being stable or growing - as one of the aspects of circular economy is a formation of strong sustainable economy based on the environmentally friendly decision making.

\section{MCDM Methods in assessment of environmental pillar in the context of circular economy}

Environmental pillar of circular economy is represented as a set of indicators divided into the group of areas. As indicators collected for environmental pillar measurement have different units of measurement - the methods of assessing environmental pillar should be selected accordingly. Multiple-criteria decision-making methods (MCDM) can be applied to assess the set of criteria with different units of measurement, could evaluate and rank the criteria. To assess environmental pillar of circular economy MULTIMOORA and TOPSIS methods have been selected.

MULTIMOORA method has been introduced by Brauers and Zavadskas (2010), who have updated MCDM method MOORA by adding multi-object optimization. MULTIMOORA method has been used by scientists from different fields: Hafezalkotob et al., (2019) has applied MULTIMOORA method in the field of Engineering by proposing of MULTIMOORA use in hybrid vehicle engine selection. Wu et al., (2020) used MULTIMOORA method in the analysis of quality function deployment. Also, MULTIMOORA method has been used by Siksnelyte, et al., (2019) in assessment of implementation of EU energy policy priorities in the Baltic Sea Region. Liet al., (2019) has used MULTIMOORA method for evaluation of passenger satisfaction of public transport. Geetha et al., (2019) has used MULTIMOORA method for assessment of healthcare waste disposal methods.

TOPSIS method based on identifying geometric distances from best and worst solutions: the shortest geometric distance from the best solution and the longest geometric distance from the worst solution (Zavadskas et al. 2016). TOPSIS method has been used in the selection of sustainable supplier by Memari et al., (2019). Comparison of sustainability models in development of electric vehicles has been presented using TOPSIS method by Samaie et al., (2020). Gorgij et al., (2019) has used TOPSIS method in the ranking of groundwater quality. Economic and environmental energy performance of EU countries has been assessed with TOPSIS method by Vavrek and Chovancova (2019). Credit card platforms have been evaluated using TOPSIS method by Yildirim (2019). 
ENTREPRENEURSHIP AND SUSTAINABILITY ISSUES

ISSN 2345-0282 (online) http://jssidoi.org/jesi/ 2020 Volume 8 Number 1 (September) http://doi.org/10.9770/jesi.2020.8.1(81)

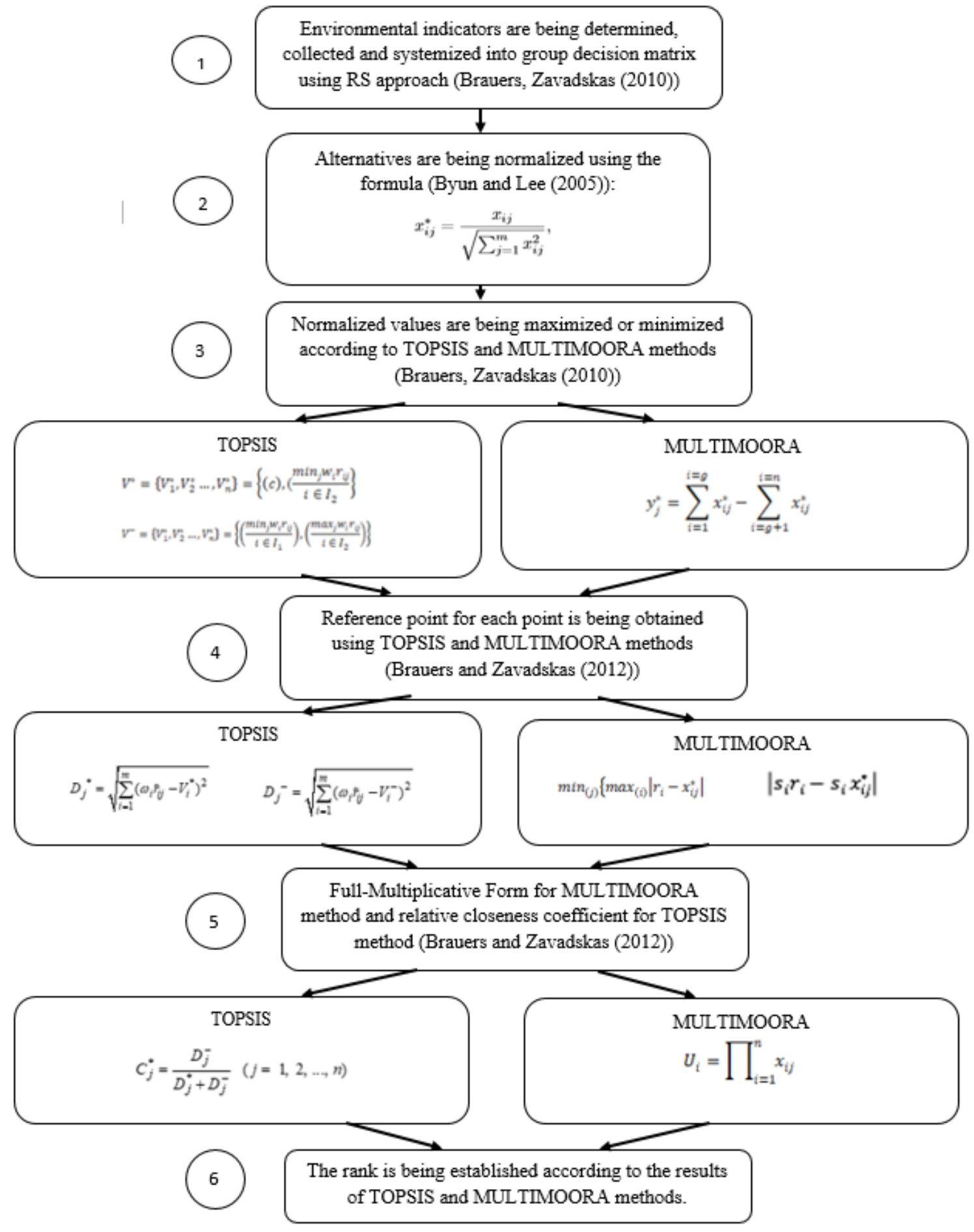

Figure 2. Assessment model of Environmental pillar in the context of Circular Economy using MULTIMOORA and TOPSIS methods

Source: created by authors 
The assessment model of Environmental pillar in the context of Circular Economy is based on 6 major steps as represented in Fig. 2. Indicators for Environmental pillar assessment in the context of Circular Economy are being collected and grouped, systemized in decision matrix. As all the indicators have various units of measurement the values are being normalized as is represented in Step 2. In Step 3 the values are being maximized or minimized according to the rules of MULTIMOORA and TOPSIS methods. Once the values have been maximized or minimized, the reference point can be found out as represented in Step 4. In Step 5 the Full-Multiplicative form for MULTIMOORA is obtained and relative closeness coefficient to the best and to the worst solutions can be obtained by MULTIMOORA and TOPSIS methods. In the last Step the rank of values can be obtained according to the result of TOPSIS and MULTIMOORA methods.

The ranking of Development of Environmental pillar in the context of Circular Economy can be assessed in the different periods of time and can be compared among selected countries or region for further analysis.

\section{The assessment of environmental pillar in the context of circular economy}

The first Macro-Regional Strategy in Europe has been established for the countries with geographical location around Baltic Sea and named Baltic Sea Region. The action plan for this strategy has been introduced by the European Commission (2009). The strategy is based on key challenges regarding saving the sea, connecting the region and increasing prosperity. The strategy has several objectives which relate to different areas and policies, such as: clean water in the sea with healthy wildlife, safe shipping, and reliable energy markets with the perspective to make a single energy market, climate change adaptation with risk management and other contributions to Europe 2020 (European Commission, 2010) strategy. Baltic Sea Region includes Sweden, Denmark, Estonia, Finland, Germany, Latvia, Lithuania and Poland.

Data for Environmental pillar s was collected in the period of 2014-2018 years using the following databases: European Statistical Database - Eurostat (2020), Organization for Economic Co-Operation and development (2020) and European Commission (2020).

Table 3. Environmental pillar evaluation of Baltic Sea Region in 2014

\begin{tabular}{|c|c|c|}
\hline MULTIMOORA & TOPSIS & Sweden \\
\hline & & \\
\hline \\
Sweden
\end{tabular}

Source: created by authors 
The result of Environmental pillar evaluation by MULTIMOORA and TOPSIS methods for 2014 is represented in Table 3. According to MULTIMOORA method the highest ranks were received by Sweden, Denmark and Finland, while the lowest rank received by Estonia and Ploand. TOPSIS result shows, that the best evaluation of Environmental pillar in 2014 were received by - Sweden, Germany and Denmark. The lowest rank according to TOPSIS method was received Poland in 2014.

The result of Environmental pillar evaluation by MULTIMOORA and TOPSIS methods for 2015 is represented in Table 4. According to MULTIMOORA method the highest ranks were attributed to Sweden, Denmark and Germany and the lowest rank attributed to Estonia. TOPSIS result shows, that the best evaluation of Environmental pillar in 2015 were ranked - Sweden, Denmark and Germany. The lowest rank according to TOPSIS method received Poland in 2015.

Table 4. Environmental pillar evaluation of Baltic Sea Region in 2015

\begin{tabular}{|c|c|c|}
\hline MULTIMOORA & TOPSIS & 2015 \\
\hline & Sweden & \\
\hline \\
Sweden
\end{tabular}

Source: created by authors

The result of Environmental pillar evaluation by MULTIMOORA and TOPSIS methods for 2016 is represented in Table 5. According to MULTIMOORA method Sweden, Denmark and Finland were tagged the highest rank and Estonia the lowest rank. In respect of this, TOPSIS result shows, that the best evaluation of Environmental pillar in 2016 received - Sweden, Germany and Denmark. The lowest rank according to TOPSIS method received Poland in 2016 therein.

The result of Environmental pillar evaluation by MULTIMOORA and TOPSIS methods for 2017 is represented in Table 6. According to MULTIMOORA method, the highest rank received were that of Sweden, Latvia and Denmark and the lowest rank received belongs to Estonia. TOPSIS result shows that the best evaluation of Environmental pillar in 2017 received were that of Germany, Sweden and Denmark. The lowest rank according to TOPSIS method received was that of Poland in 2017. 
Table 5. Environmental pillar evaluation of Baltic Sea Region in 2016

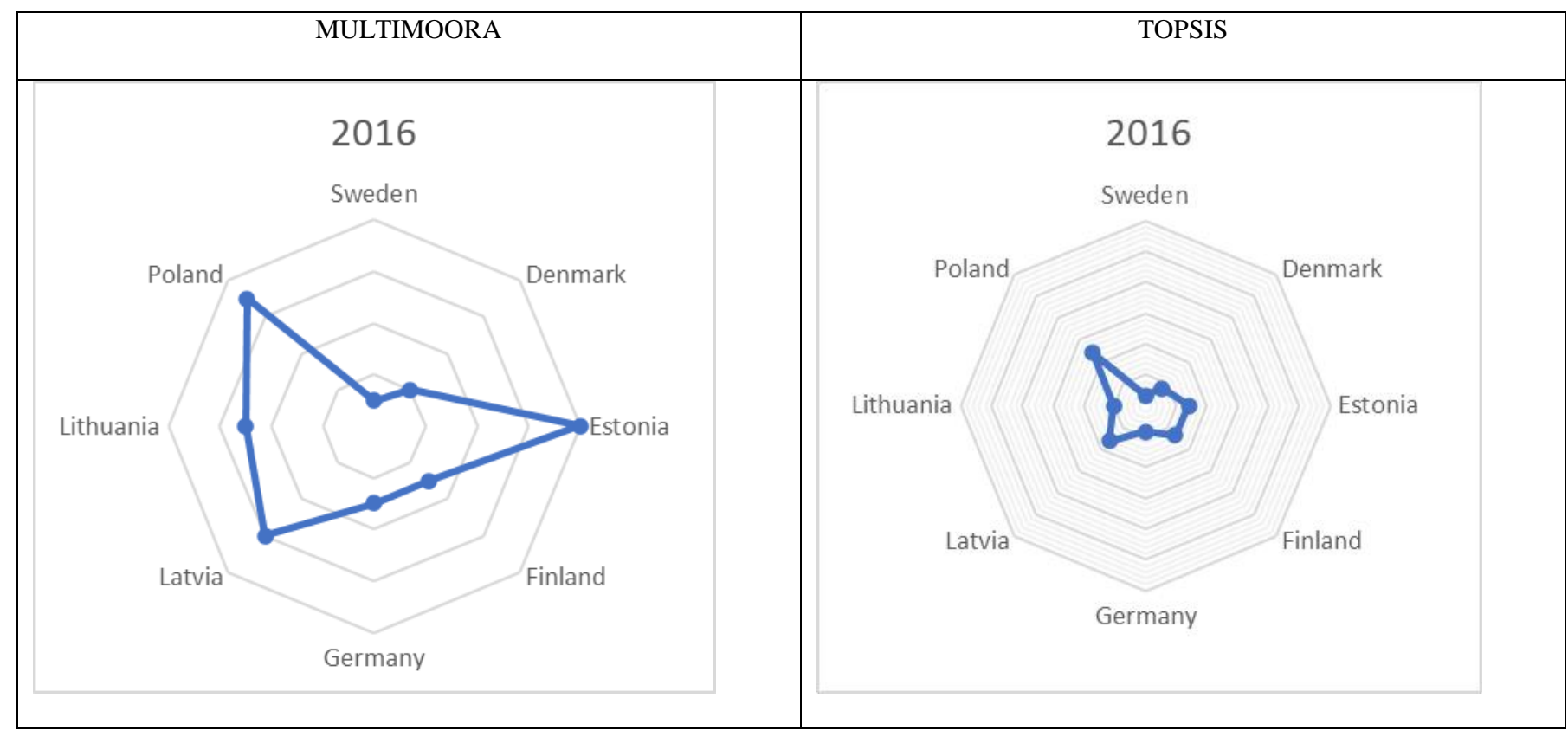

Source: created by authors

Table 6. Environmental pillar evaluation of Baltic Sea Region in 2017

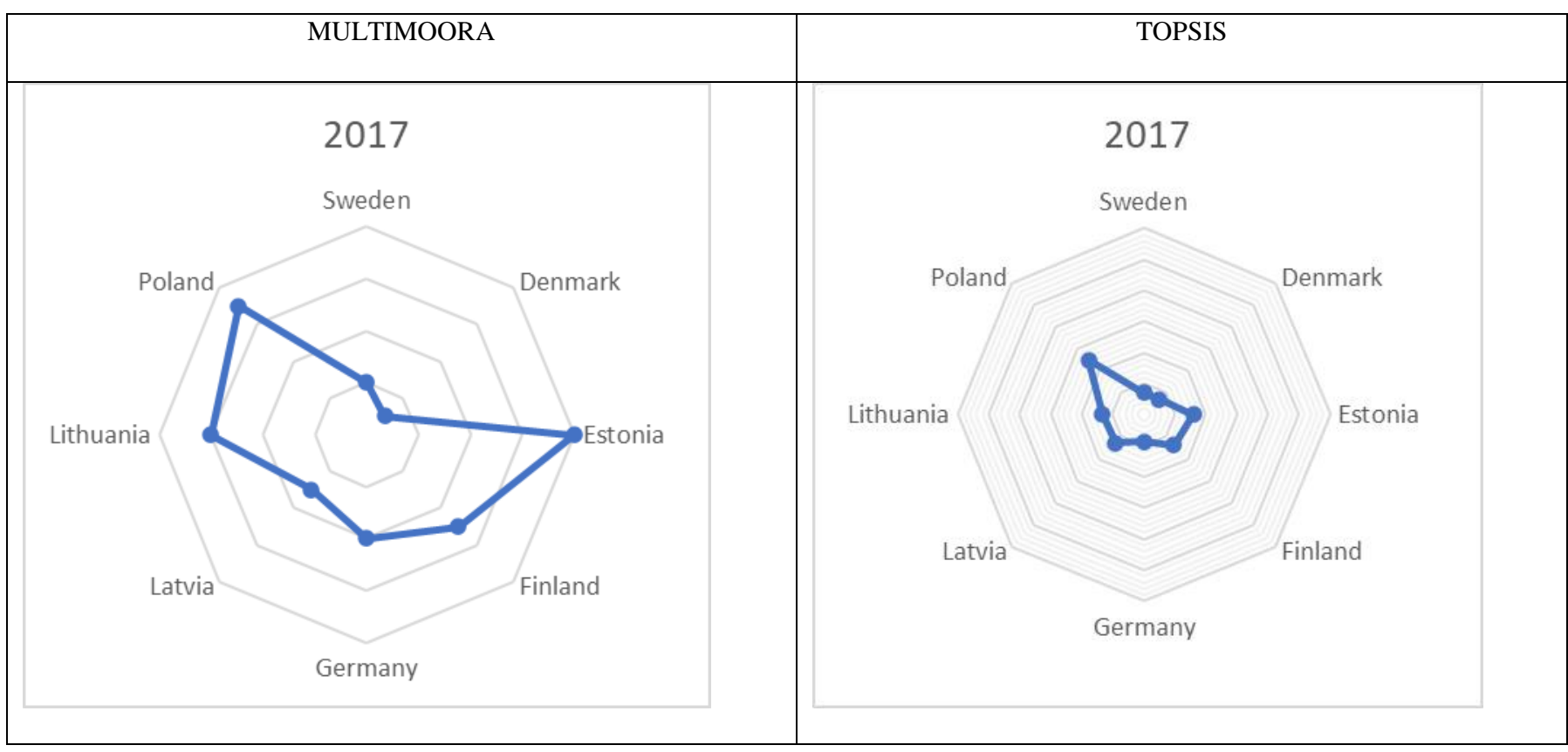

Source: created by authors

The result of Environmental pillar evaluation by MULTIMOORA and TOPSIS methods for 2018 is represented in Table 7. According to MULTIMOORA method, the highest rank received were that of Sweden, Germany and 
Denmark and the lowest rank received belongs to Estonia. TOPSIS result shows, that the best evaluation of Environmental pillar in 2018 received were that of Sweden, Germany and Denmark. The lowest rank according to TOPSIS method received was that of Poland in 2018.

Table 7. Environmental pillar evaluation of Baltic Sea Region in 2018

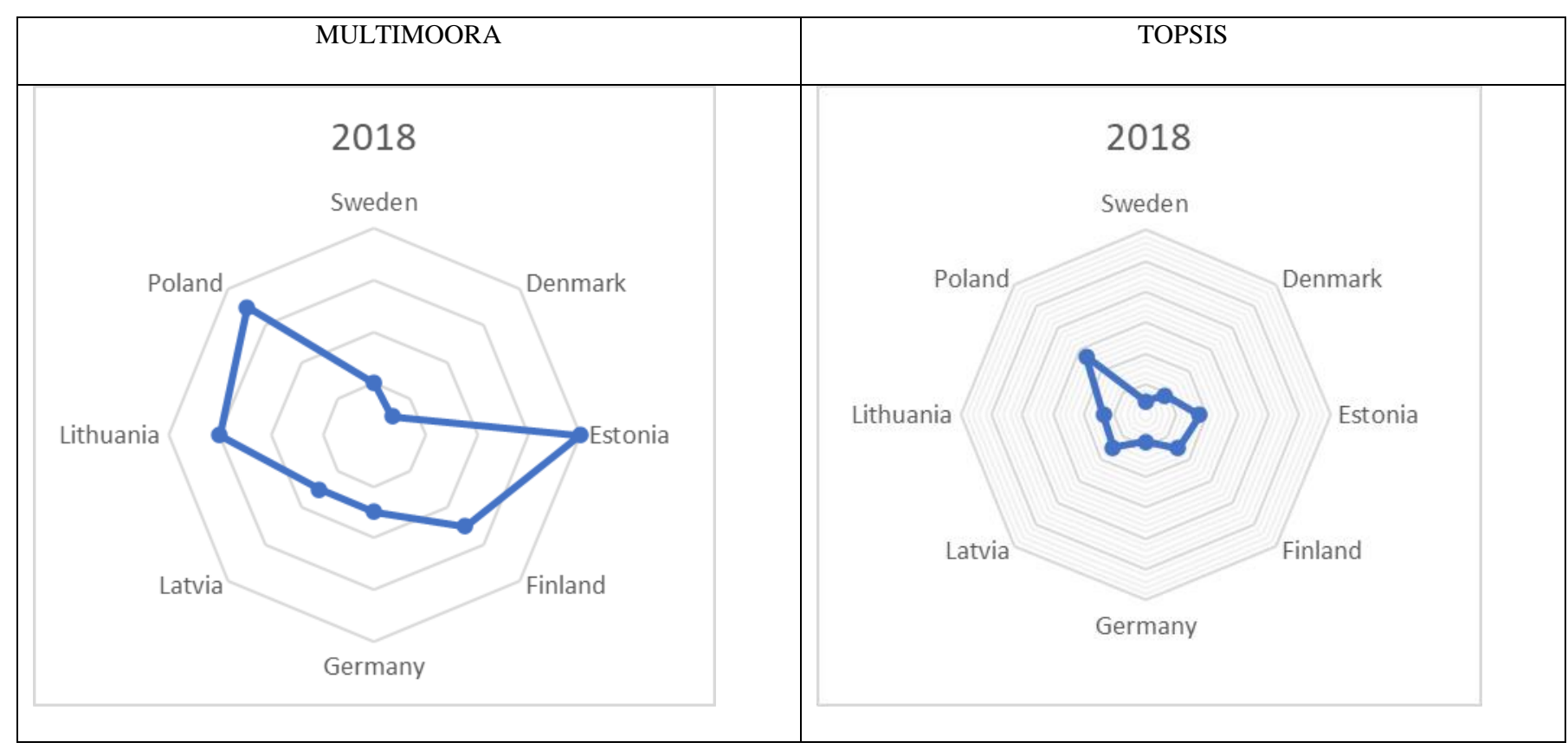

Source: created by authors

The development of Environmental pillar in Baltic Sea Region in the context of Circular Economy during the period of 2014-2018 according to MULTIMOORA is represented in Fig. 3. Sweden was in the leading position in development of Environmental pillar, moreover, in the end of 2018 Denmark has strengthen its position to be a leader among all the countries in Baltic Sea Region. In 2014 Sweden had the highest result of Environmental pillar, but in 4 years Denmark could overcome. Germany and Latvia hold the third position after Denmark and Sweden according to MULTIMOORA. In addition to this, by 2018 Germany, Latvia, Estonia and Poland did not improve the results during all the period. Finland according to MULTIMOORA decreased in the evaluation of Environmental pillar during 2014-2018. Lithuania, according to MULTIMOORA, improved the result of Environmental pillar assessment by 2018 . 


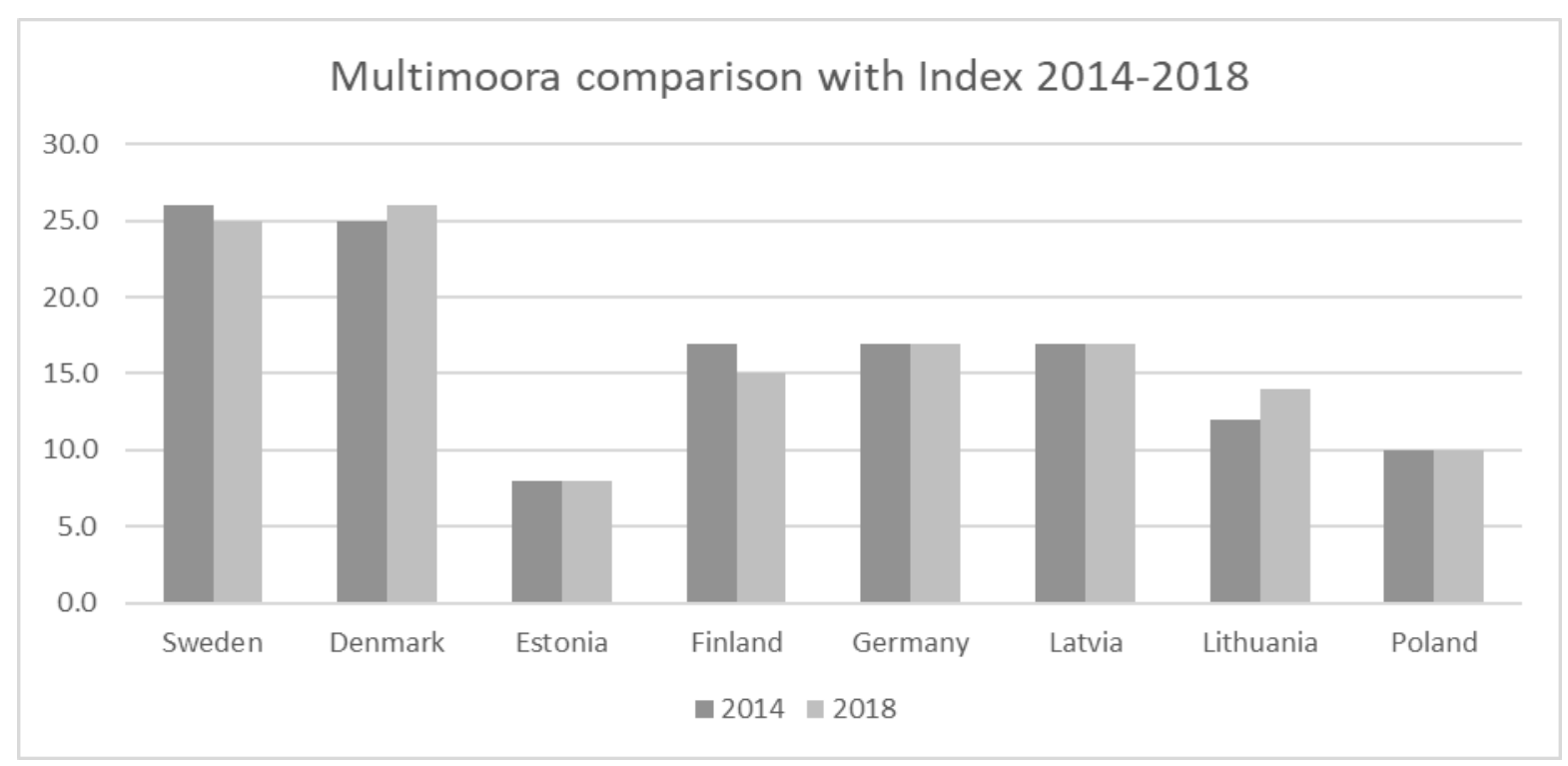

Figure 3. Development of Environmental pillar in Baltic Sea Region in the period of 2014-2018 represented by MULTIMOORA

Source: created by authors

The development of Environmental pillar in Baltic Sea Region in the context of Circular Economy during the period of 2014-2018 according to TOPSIS is represented in Fig. 4. According to TOPSIS results Sweden, Denmark and Germany are in the leading positions. Estonia and Lithuania have improved the result by 2018 while Denmark (still remains the leading position), Finland and Poland have decreased the result by 2018. Germany, Latvia, and Sweden did not reach any significant progress in Environmental pillar in the period of 2014-2018.

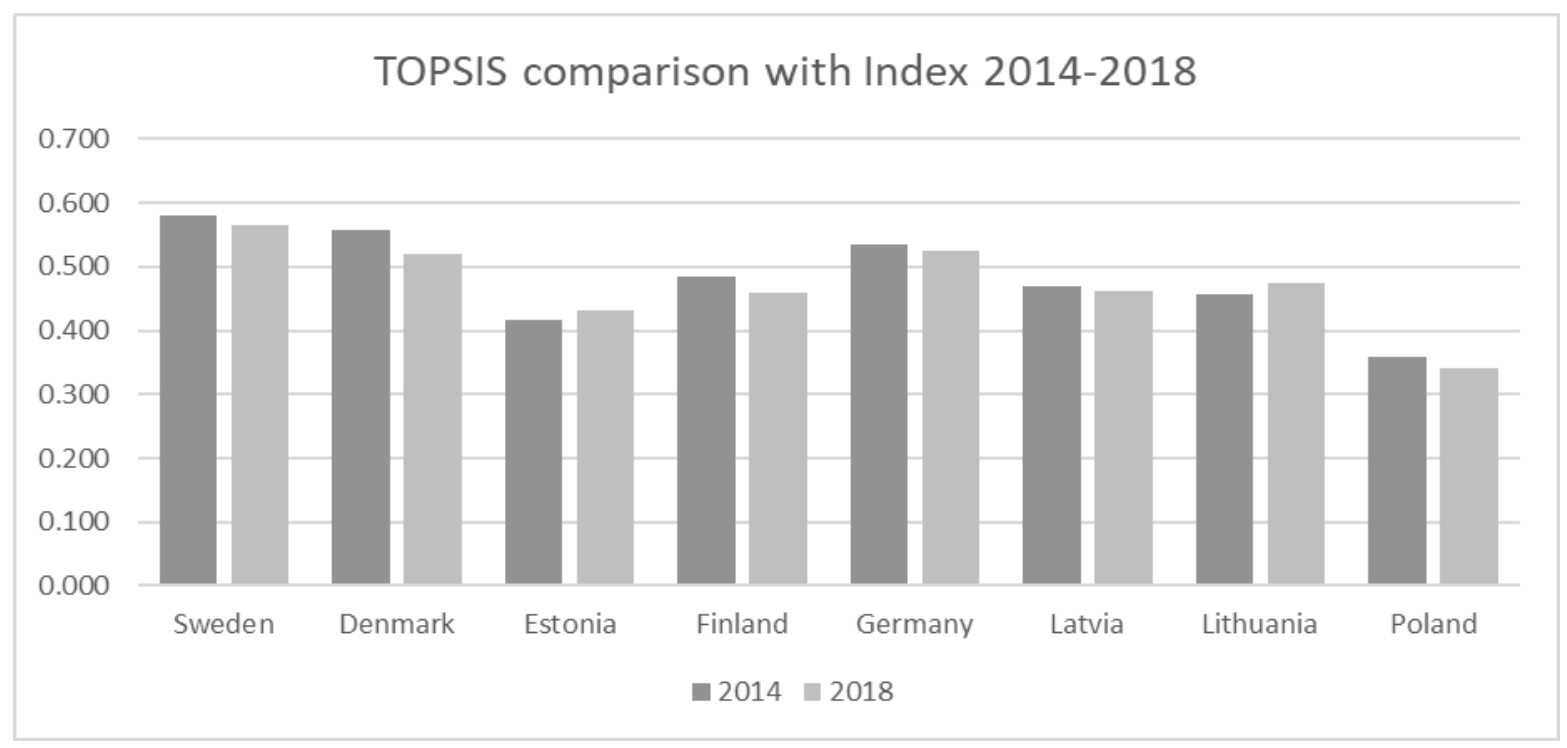

Figure 4. Development of Environmental pillar in Baltic Sea Region in the period of 2014-2018 represented by TOPSIS.

Source: created by authors 
The development of Environmental pillar in Baltic Sea Region and development of Eco-innovation in the context of Circular Economy is represented in Fig. 5. According to the data represented, it is possible to see the tendency of growing or decreasing of Environmental pillar in the context of Circular Economy. The represented data is already ranked according to MULTIMOORA and TOPSIS. The gradient shows the ranked position of the selected country by the year - the darker font means lower rank the country owes, and opposite, the lighter font the higher position holds the country.

Germany has been evaluated by MULTIMOORA and TOPSIS with the rank 2-3 in the period of 2014-2018, what is middle position, close to the leading position.

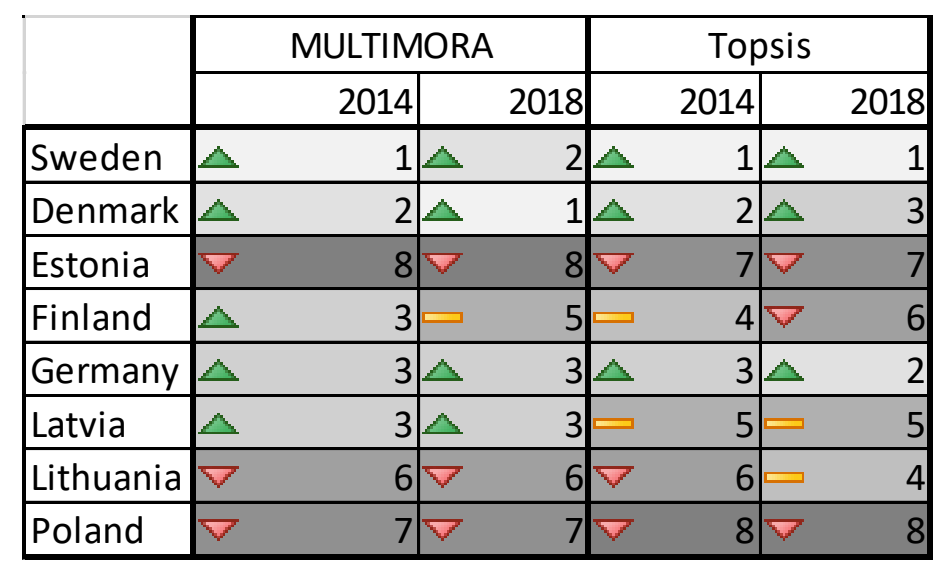

Figure 5. Development of Environmental pillar of Circular Economy assessed using MULTIMOORA and TOPSIS methods in Baltic Sea Region in 2014-2018.

Source: created by authors

To sum up, the assessment of Environmental pillar shows the development of Environmental pillar in the context of Circular Economy. TOPSIS and MULTIMOORA methods identified the leading countries in development of Environmental pillar in the context of Circular Economy which are Sweden, Denmark and Germany. Also, according to TOPSIS and MULTIMOORA methods the lowest ranks got countries: Lithuania, Estonia and Poland. Finland and Latvia have been ranked in the middle by MULTIMOORA and TOPSIS methods.

\section{Conclusion}

Circular Economy is an opposite economic approach to Linear Economy, which integrates Environmental aspects in Economic model. Opposite than Linear Economy, which promotes "take, make, dispose" approach, Circular Economy suggest representing Economic model as a closed loop with high attention to Environment on every step of production and consumption.

Environmental pillar of Circular Economy is a multidisciplinary approach, connecting Environmental and Social sciences. The set of indicators are being selected based on European Union policies, promoting Sustainable Development and Circular Economy. Based on established strategies and targets indicators are being grouped according to the aim of the target - which make a system of indicators representing Environmental pillar of Circular Economy. 


\section{ENTREPRENEURSHIP AND SUSTAINABILITY ISSUES}

ISSN 2345-0282 (online) http://jssidoi.org/jesi/ 2020 Volume 8 Number 1 (September)

http://doi.org/10.9770/jesi.2020.8.1(81)

Environment pillar has been analyzed in Baltic Sea Region in the period of 2014-2018 using MULTIMOORAand TOPSIS methods. Based on MULTIMOORA and TOPSIS methods the assessment model of Environmental pillar has been proposed. According to proposed assessment model of Circular Economy the countries are being ranked based on the result of applied MCDM methods.

The results of MULTIMOORA and TOPSIS methods shows similar evaluation of the development of Environmental pillar in the context of Circular Economy. As e research shows the best development of Environmental pillar show Sweden, Denmark and Germany. Finland and Lithuania have been middle-ranked by MULTIMOORA and TOPSIS. Lowest ranks got Lithuania, Estonia and Poland using MULTIMOORA and TOPSIS methods. The assessment model of Environmental pillar allows to analyze and follow the dynamics of development of Environmental pillar Circular Economy, allowes to include it to the complex evaluation of Circular Economy.

\section{References}

Bjørn, A., Bey, N., Georg, S., Røpke, I., \& Hauschild, M. Z. (2017). Is Earth recognized as a finite system incorporate responsibility reporting? Journal of Cleaner Production, 163, 106-117. https://doi.org/10.1016/j.jclepro.2015.12.095

Brauers, W. K. M., Zavadskas E. K., 2012. Robustness of MULTIMOORA: A method for multi-Objective Optimization. Informatica, 23,1-25. https://doi.org/10.15388/Informatica.2012.346

Brauers, W.K.M., Zavadskas, E.K. 2010. Robustness in the MULTIMOORA model: the example of Tanzania. Transformations in Business and Economics, 9(3), 67-83.

Byun, H. S., Lee, K. H., 2005. A Decision Support System for the Selection of a Rapid Prototyping Process Using the Modified TOPSIS Method. International Journal of Advanced Manufacturing Technology, 26, 1338-47.

EC, 2011. Roadmap to a Resource Efficient Europe - COM(2011) 571 Final, European Commission, Brussels. https://www.eea.europa.eu/policy-documents/com-2011-571-roadmap-to

EC, 2015. Closing the Loop - an EU Action Plan for the Circular Economy - COM(2015) 614 Final. Brussels. https://www.eea.europa.eu/policy-documents/com-2015-0614-final

EC, 2018. Measuring Progress Towards Circular Economy in the European Union - Key Indicators for a Monitoring Framework SWD(2018) 17 Final. European Commission, Strasbourg. https://ec.europa.eu/environment/circular-economy/pdf/monitoringframework_staff-working-document.pdf

European Commission 2010. Strategy "EUROPE 2020". Internet source accessed in 2020: https://ec.europa.eu/eu2020/pdf/COMPLET\%20EN\%20BARROSO\%20\%20\%20007\%20-\%20Europe\%202020\%20-

\%20EN\%20version.pdf

European Commission 2020. ECO-Innovation Index. Internet source accessed in 2020: https://ec.europa.eu/environment/ecoap/indicators/index_en

European Commission, 2009. European Union Strategy for the Baltic Sea Region. Internet source accessed in 2020: https://ec.europa.eu/regional policy/sources/docoffic/official/communic/baltic/action 10092015 en.pdf

Eurostat database. 2020. Circular Economy and Environmental Indicators. Internet source accessed in 2020: http://appsso.eurostat.ec.europa.eu/nui/show.do?dataset=nrg_109a\&lang=en

Geetha, S., Narayanamoorthy, S., Kang, D., Kureethara, J. V. 2019. A Novel Assessment of Healthcare Waste Disposal Methods: Intuitionistic Hesitant Fuzzy MULTIMOORA Decision Making Approach, IEEE Access, vol. 7. https://doi.org/10.1109/ACCESS.2019.2940540

Geng, Y., Doberstein, B. 2008. Developing circular economy in China: challenges and opportunities for achieving "leapfrog development". International Journal of Sustainable Development and World Ecology, 15(3), 231-239. https://doi.org/10.3843/SusDev.15.3:6

Geng, Y., Fu, J., Sarkis, J., Xue, B. 2012. Towards a national circular economy indicator system in China: an evaluation and critical analysis. Journal of Cleaner Production, 23, 216-224. https://doi.org/doi:10.1016/j.jclepro.2011.07.005 


\section{ENTREPRENEURSHIP AND SUSTAINABILITY ISSUES}

ISSN 2345-0282 (online) http://jssidoi.org/jesi/ 2020 Volume 8 Number 1 (September)

http://doi.org/10.9770/jesi.2020.8.1(81)

Ghisellini P., Cialani C., Ulgiati S. 2016. A review on circular economy: the expected transition to a balanced interplay of environmental and economic systems. Journal of Cleaner Production, 114, 11-32. https://doi.org/10.1016/j.jclepro.2015.09.007

Gorgij, A. D., Wu, J., Moghadam A.A. 2019. Groundwater quality ranking using the improved entropy TOPSIS method: a case study in Azarshahr plain aquifer, east Azerbaijan, Iran, Human and Ecological Risk Assessment: An International Journal. 25(1-2), 176-190. https://doi.org/10.1080/10807039.2018.1564235

Hafezalkotob, A., Hafezalkotob, A., Liao, H., Herrera, F., 2019. Interval MULTIMOORA Method Integrating Interval Borda Rule and Interval Best-Worst-Method-Based Weighting Model: Case Study on Hybrid Vehicle Engine Selection. IEEE transactions on cybernetics, 50(3). https://doi.org/10.1109/tcyb.2018.2889730

Homrich, A.S., Galvão, G., Abadia, L.G., Carvalho, M.M. 2018. The circular economy umbrella: trends and gaps on integrating pathways, Journal of Clean Production, 175 (2018), 525-543. https://doi.org/10.1016/j.jclepro.2017.11.064

Lewandowski, M. 2016. Designing the business models for circular economy-Towards the conceptual framework. Sustainability, 8(1), 43. https://doi.org/10.3390/su8010043

Li, J., H. Lu, J. Guo, Z. Xu, and Y. Zhou. 2007. Recycle technology for recovering resources and products from waste printed circuit boards. Environmental Science \& Technology, 41(6), 1995-2000. https://doi.org/10.1021/es0618245

Li, X., Huang, L., Li, Q., Liu, H. 2020. Passenger Satisfaction Evaluation of Public Transportation Using Pythagorean Fuzzy MULTIMOORA Method under Large Group Environment. Sustainability, 12(12), 4996. https://doi.org/10.3390/su12124996

Memari, A., Dargi, A., Jokar, M.R.A., Ahmad, R., Rahim, A. R. A. 2019. Sustainable supplier selection: A multi-criteria intuitionistic fuzzy TOPSIS method. Journal of Manufacturing Systems, 50, 9-24. https://doi.org/10.1016/j.jmsy.2018.11.002

Morseletto, P. 2020. Targets for Circular Economy. Resources, Conservation and Recycling, 153 , 104553. https://doi.org/10.1016/j.resconrec.2019.104553

Nikanorova, M., Imoniana, J. O., Stankevičienè, J. 2020. Analysis of social dimension and well-being in the context of circular economy. International Journal of Global Warming, 21(3). https://doi.org/10.1504/IJGW.2020.108678

Organization for Economic Co-Operation and development (2020). Green Growth Indicators. Internet source accessed in 2020: http://stats.oecd.org/Index.aspx?DataSetCode=GREEN GROWTH\#

Potting, J., Hekkert, M., Worrell, E., Hanemaaijer, A. 2017. Circular Economy: Measuring Innovation in the Product Chain, PBLNetherlands Environmental Assessment Agency. https://dspace.library.uu.nl/handle/1874/358310

Repo, P., Anttonen, M., Mykkanen, J., Lammi, M. 2018. Lack of congruence between European citizen perspectives and policies on circular economy. Eur. J. Sustain. Dev., 7(1), 249-264. https://doi.org/10.14207/ejsd.2018.v7n1p249

Samaie, F., Meyar-Naimi, H., Javadi, S., Feshki-Farahani, H. 2020. Comparison of sustainability models in development of electric vehicles in Tehran using fuzzy TOPSIS method. Sustainable Cities and Society, 53, 101912. https://doi.org/10.1016/j.scs.2019.101912

Schroeder, P., Anggraeni, K, Weber, U., 2018. The Relevance of Circular Economy Practices to the Sustainable Development Goals, Research and Analysis, Vol. 23. https://doi.org/10.1111/jiec.12732

Siksnelyte, I., Zavadskas, E. K., Bausys, R., Streimikiene, D. (2019). Implementation of EU energy policy priorities in the Baltic Sea Region countries: Sustainability assessment based on neutrosophic MULTIMOORA method. Energy Policy, 125, 90-102 https://doi.org/10.1016/j.enpol.2018.10.013

Vavrek, R., Chovancova, J. 2019. Assessment of economic and environmental energy performance of EU countries using CV-TOPSIS technique. Ecological Indicators, 106, 105519. https://doi.org/10.1016/j.ecolind.2019.105519

Wu, S. M., You, X. Y., Liu, H. C., Wang, L.E. 2020. Improving quality function deployment analysis with the cloud MULTIMOORA method, International Transactions in Operational Research, 27, 1600-1621. https://doi.org/10.1111/itor.12484

Yildirim, B.F. 2019. Evaluation of Credit Card Platforms Using Intuitionistic Fuzzy TOPSIS Method. Journal of BRSA Banking and Financial Markets, Banking Regulation and Supervision Agency, 13(1), 37-58.

Zavadskas, E. K., Mardani, A., Turskis, Z., Jusoh, A., MD Nor, K. (2016). Development of TOPSIS Method to Solve Complicated Decision-Making Problems: An Overview on Developments from 2000 to 2015. International Journal of Information Technology \& Decision Making, 15, 1-37. https://doi.org/10.1142/S0219622016300019 


\section{ENTREPRENEURSHIP AND SUSTAINABILITY ISSUES}

ISSN 2345-0282 (online) http://jssidoi.org/jesi/ 2020 Volume 8 Number 1 (September)

http://doi.org/10.9770/jesi.2020.8.1(81)

Marta NIKANOROVA is is a PhD student of Economics of Financial Engineering Department at the Faculty of Business Management, Vilnius Gediminas Technical University, Lithuania. Research interests: circular economy; eco-innovations; zero-waste economy; sustainability.

ORCID ID: orcid.org/0000-0002-1947-9766

Jelena STANKEVIČIENÉ is a Professor of Economics of Financial Engineering Department at the Faculty of Business Management, Vilnius Gediminas Technical University, Lithuania. She is an editor-in-chief of the journal of Business, Management and Education. Her main research topics include assets and liability management, regulation of financial institution, financial management for value creation, value engineering. Her latest research is concerned with economic modelling, input-output models analysis, fintech and green economy.

ORCID ID: orcid.org/0000-0002-5600-5842

Make your research more visible, join the Twitter account of ENTREPRENEURSHIP AND SUSTAINABILITY ISSUES:

@ Entrepr69728810

Copyright (C) 2020 by author(s) and VsI Entrepreneurship and Sustainability Center

This work is licensed under the Creative Commons Attribution International License (CC BY).

http://creativecommons.org/licenses/by/4.0/

(c) (i) Open Access 